\title{
Mineral chemistry (biotite, muscovite, garnet, and plagioclase) in the Kathmandu and Gosainkund regions, central Nepal Himalaya
}

\author{
*S. M. Rai ${ }^{\prime}$, S. Guillot ${ }^{2}$, B. N. Upreti ${ }^{l}$, A. Pêcher ${ }^{3}$, and P. Le Fort ${ }^{+}$ \\ 'Department of Geology, Tri-Chandra Campus, Tribhuvan University, \\ Ghantaghar, Kathmandu, Nepal \\ ${ }^{2}$ Laboratoire de Dynamique de la Lithospère, CNRS UMR 5570, ENS-Lyon, \\ 27 bd du 11 Novembre, Villeurbanne, France \\ ${ }^{3}$ Université de Grenoble et CNRS, Laboratoire de Geodynamiques des Chaines Alpines, \\ 38031 Grenoble Cedex, France \\ ${ }^{4}$ Bureau du CNRS, Moscow, Russia \\ (*Email: santamanrai@yahoo.com)
}

\begin{abstract}
The greenschist- to granulite-facies rocks in the Kathmandu and Gosainkund regions are divided into three tectonic units on the basis of structure, lithology, and metamorphism. The Gosainkund Crystalline Nappe (GCN) corresponds to the southward extension of the Higher Himalayan Crystallines (HHC), which thrusts over the Kathmandu Crystalline Nappe $(\mathrm{KCN})$ along the Main Central Thrust (MCT). The GCN and KCN thrust over the Lesser Himalaya (LH) along the MCT and the Mahabharat Thrust (MT), respectively.

Systematic traverses with the microprobe of four minerals (i.e., biotite, muscovite, garnet, and plagioclase) from all the three units were carried out to study their chemical variations. Most of the biotite compositions from all units belong to the annite compositional field. There is an inverse relationship between the Ti and the $\mathrm{Mg}$ number $\left(\mathrm{Mg}^{2+} /\left(\mathrm{Mg}^{2+}+\mathrm{Fe}^{2+}\right)\right.$ and the latter increases from the top to bottom section of the KCN. The LH biotites resemble the bottom composition of the KCN whereas the GCN biotite compositions are quite scattered. However, the Ti-Mg number trend does not seem to be related directly to the grade of metamorphism. The muscovites from the $\mathrm{KCN}$ are rich in $\mathrm{FeO}$ while the muscovites from other two units are rich in $\mathrm{Al}_{2} \mathrm{O}_{3}$. In the $\mathrm{KCN}$, the almandine and pyrope contents in garnet decrease from bottom to top section, while the grossular and spessartine contents in garnet increase. This trend is consistent with the prograde metamorphic evolution observed in the field. The composition of garnets from the bottom to the top section of the GCN does not show any systematic variation, but in the upper section, where sillimanite appears, the almandine content decreases and th, spessartine content slightly increases. This variation in composition suggests a polyphase metamorphic evolution. The albite content of plagioclase decreases from the lower to upper section in the KCN while there is not any systematic variation in the GCN.

The P-T conditions record the good preservation of inverse metamorphism in the LH below the MCT. The comparison of P-T results between the $\mathrm{KCN}$ and the GCN suggests that exhumation of the KCN was followed by the exhumation of the GCN.
\end{abstract}

\section{INTRODUCTION}

The collision between the Indian and Eurasian continental plates occurred in the Eocene epoch and resulted in the development of the Himalayan Range. The Indian crust was under thrust along a series of faults that divide the Himalayan orogen into four major intercontinental thrust packages, which are the Tethys Himalaya, Higher Himalaya, Lesser Himalaya, and Sub-Himalaya from north to south, respectively (Gansser 1964). Most of the researchers in the Himalaya recognize the Main Central Thrust (MCT) as a major syn-to post-collisional intracrustal fault extending throughout most of the Himalayan Range (Gansser 1964, Hashimoto et al. 1973, Le Fort 1975, Valdiya 1980, Pêcher 1989). The present study was carried out to study metamorphic history on the basis of petrography, mineral chemistry, and P-T conditions of the crystalline sheets of both nappes and the upper section of the LH.

\section{GEOLOGICAL SETTING}

The study area comprises three tectonic units (Fig. 1). From south to north, they are the Lesser Himalaya (LH), the Kathmandu Crystalline Nappe (KCN), and the Gosainkund Crystalline Nappe (GCN) (Figs. 1 and 2). The GCN overthrusts the KCN along the Main Central Thrust (MCT). The GCN and $\mathrm{KCN}$ thrust over the $\mathrm{LH}$ along the MCT and the Mahabharat Thrust (MT), respectively.

The LH is composed of Late Precambrian to Palaeozoic sedimentary to metasedimentary rocks of greenschist to amphibolite facies, such as limestone, dolomite, gritstone, conglomerate, slate, phyllite, schist, metasandstone, quartzite, Lesser Himalayan augen gneiss (Ulleri type augen gneiss), and amphibolite. The $\mathrm{KCN}$ is equivalent to the Kathmandu Complex (Stöcklin and Bhattarai 1977, Stöcklin 1980), and it is divided into the Bhimphedi Group 
and Phulchauki Group (Fig. 2). The rocks of the Kathmandu Complex are considered to be the rocks of the HHC, which thrust over the rocks of the LH along the MT, and is an extension of the MCT (Stöcklin 1980; Fuchs 1981; Pêcher and Le Fort 1986; Pandey et al. 1995). The recent work carried out by Upreti and Le Fort (1999), Rai et al. (1998), Rai (1998, $2001)$ proposed two thrust packages (KCN to the south and GCN to the north), separated by the MCT in the Kathmandu region on the basis of stratigraphy, lithology, and metamorphism (Figs. 2 and 3). The lower unit (Bhimphedi Group) of the KCN is composed of amphibolite-facies rocks (phyllite, schist, metasandstone, quartzite, and marble of Precambrian age). The upper unit (Phulchauki Group) of the $\mathrm{KCN}$ consists of greenschist-facies rocks and sedimentary rocks of the Lower Palaeozoic age (limestone, slate, metasandstone, phyllite, calc-phyllite, and marble). The GCN, which occurs south of the Langtang area and which is equivalent to the HHC, consists of amphibolite-granulitefacies rocks (Figs. 2 and 3 ). This unit is composed of paragneiss, banded gneiss, micaschist, orthogneiss, augen gneiss, migmatite, calc-silicate gneiss, and quartzite. The Nardanda Pegmatite is exposed in the north of the Kathmandu valley as a narrow belt. It is about $15 \mathrm{~km}$ long in the $\mathrm{E}-\mathrm{W}$ direction.

\section{PETROGRAPHY}

The metapelites of the $\mathrm{LH}$ are represented by the chlorite to garnet ( \pm staurolite, \pm kyanite) zone. Chlorite, the main metamorphic mineral in the chlorite zone, is obliquely oriented with respect to the primary stratification in phyllite. In the biotite zone, the characteristic mineral assemblage is biotitechlorite \pm calcite in the schists. In the garnet zone, the characteristic mineral assemblages are garnet-biotitechlorite; garnet-biotite; and garnet-biotite-plagioclasestaurolite \pm rutile in the schist and impure quartzite. Quartz is present in all metamorphic rocks. The metabasic rocks consist of hornblende, plagioclase, biotite, and epidote. The main foliation, related to the movement along the MCT or MT, is marked by biotite and muscovite, and some garnets contain syn-kinematic, sigmoidal inclusion trails. Mineralogy of the studied samples (quartz is in excess) is presented in Table 1.

The metapelites of the KCN are marked by the biotite and garnet zones. The characteristic mineral assemblage in the biotite zone is biotite-chlorite in phyllite and schist. In the garnet zone, garnet-biotite-chlorite \pm staurolite; garnetbiotite \pm chlorite \pm rutile; and garnet-biotite-staurolite \pm epidote \pm hornblende are the characteristic mineral assemblages in the micaschist. The main foliation is marked by biotite and muscovite. Mineralogy of the studied samples is presented in Table 1 .

In the $\mathrm{GCN}$, the characteristic mineral assemblages in metapelitic rocks are garnet-biotite; garnet-staurolite-biotite; kyanite-garnet-biotite; kyanite-garnet-biotite-potassium feldspar; kyanite-garnet-biotite \pm potassium feldspar \pm rutile; and sillimanite-kyanite-garnet-biotite-potassium feldspar.

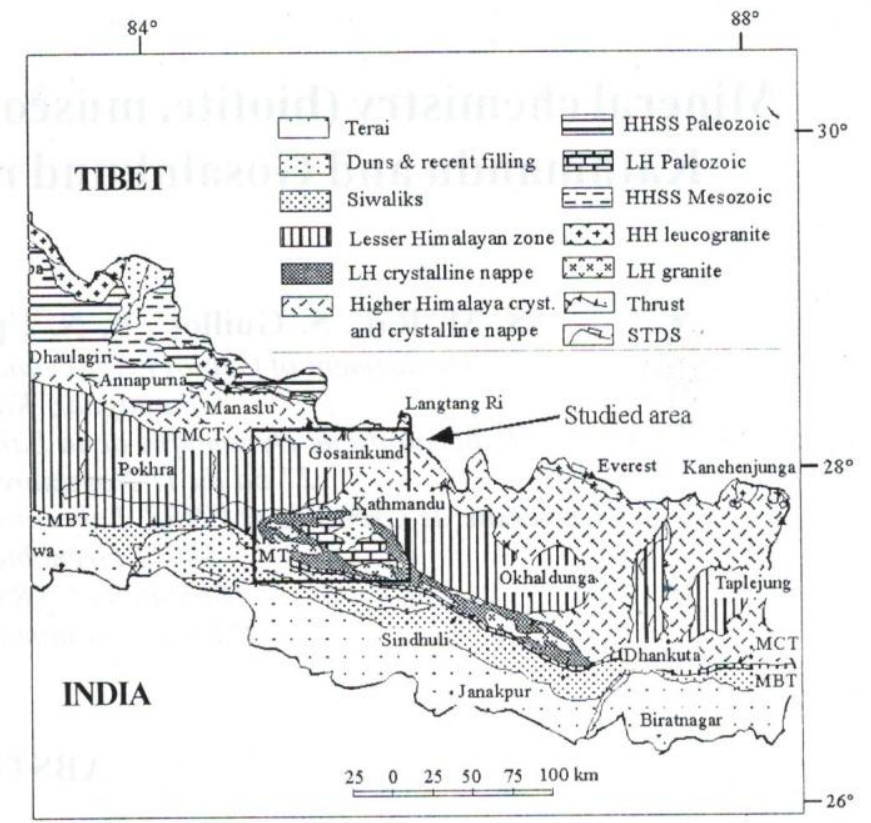

Fig. 1: Geological map of Nepal (Upreti and Le Fort 1999). HH leucogranite: Higher Himalayan leucogranite, HHSS Mesozoic: Tethyan Sedimentary Series (Mesozoic) of the Higher Himalaya, HHSS Paleozoic: Tethyan Sedimentary Series (Paleozoic) of the Higher Himalaya, LH crystalline nappe: Lesser Himalayan crystalline nappe, LH granite: "Lesser Himalayan" granite, LH Paleozoic: Sedimentary Series (Paleozoic) of the Lesser Himalayan nappes (Phulchauki Group), MBT: Main Boundary Thrust, MCT: Main Central Thrust, MT: Mahabharat Thrust,STDS: South Tibetan Detachment System

The psammitic rocks consist of a garnet-biotite assemblage and a sillimanite-biotite assemblage. The calcareous gneiss is composed of calcite, quartz, plagioclase, garnet, pyroxene, and amphibole, while the augen gneiss and granitic gneiss are composed of garnet, biotite, muscovite, potassium feldspar, plagioclase, quartz, \pm kyanite or sillimanite. These mineral assemblages belong to the garnet to sillimanite zone. Mineralogy of the studied samples is presented in Table 1.

\section{CHEMISTRY OF MINERALS}

Two samples (LO209 and LO214) from the upper section of the LH, seven samples (KN274, KN443, KN623, KN863, $\mathrm{KN} 876, \mathrm{KN} 879, \mathrm{KN} 881$ ) from the $\mathrm{KCN}$ and nine samples (KN74, KN87, KN91, KN225, KN244, KN299, KN522, KN524, $\mathrm{KN} 648$ ) from the GCN were collected for the study of chemistry of the minerals (Fig. 2). The microprobe analyses were carried out in the Institute Polytechnique de Grenoble, France, on CAMEBAX SX-50 microprobe. The accelerating voltage was $15 \mathrm{kV}$ for a sample current of $15.1 \mathrm{nA}$ and counting time of $10 \mathrm{~s}$. Standards were natural silicates and oxides. Representative results of mineral analyses are presented in Table 2. 
Mineral chemistry in Kathmandu and Gosainkund regions

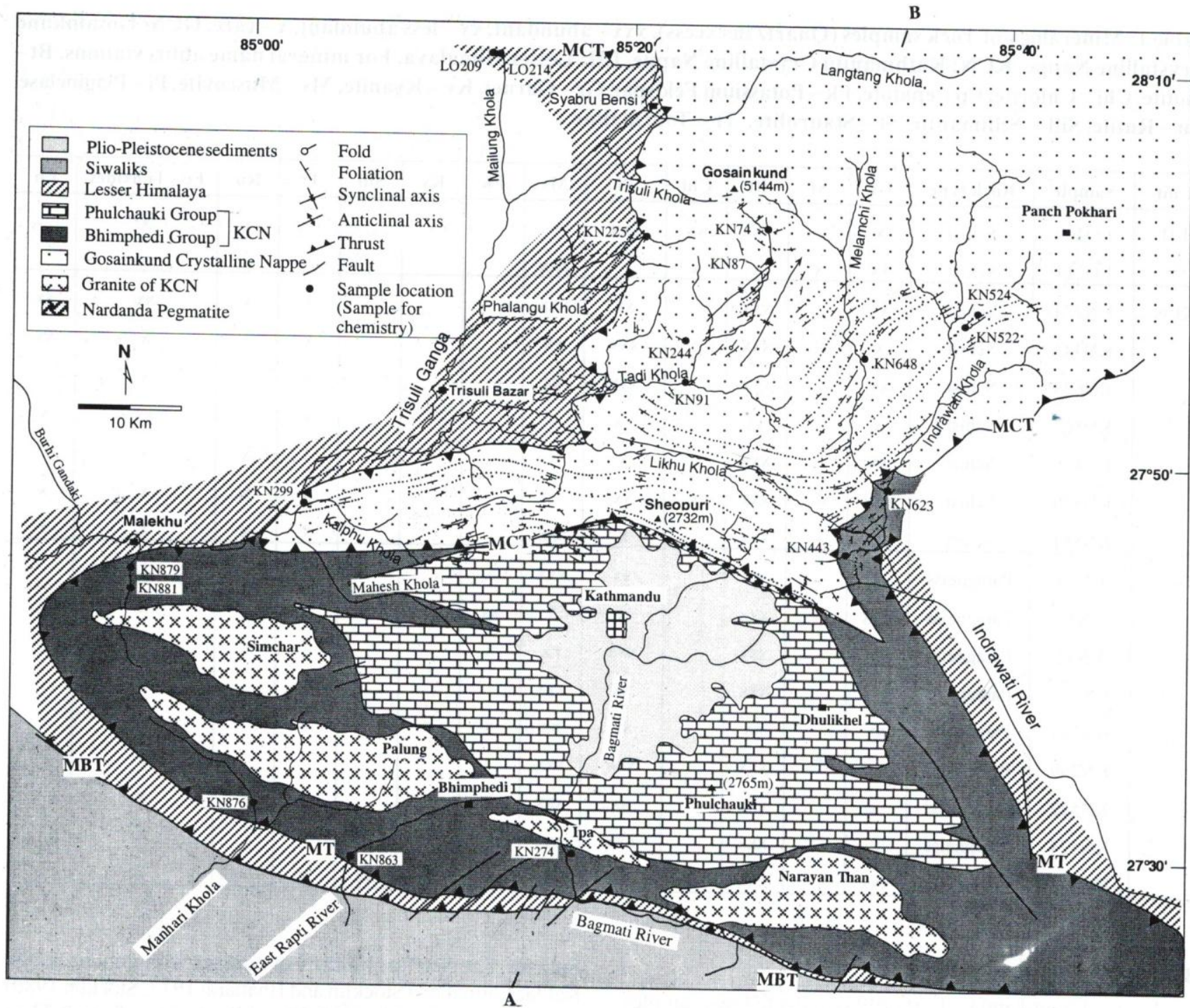

Fig. 2: Geological map of Central Nepal (modified after Stöcklin 1980) with foliation trajectories in the studied area. KCN: Kathmandu Crystalline Nappe, MBT: Main Boundary Thrust, MCT: Main Central Thrust, MT: Mahabharat Thrust A

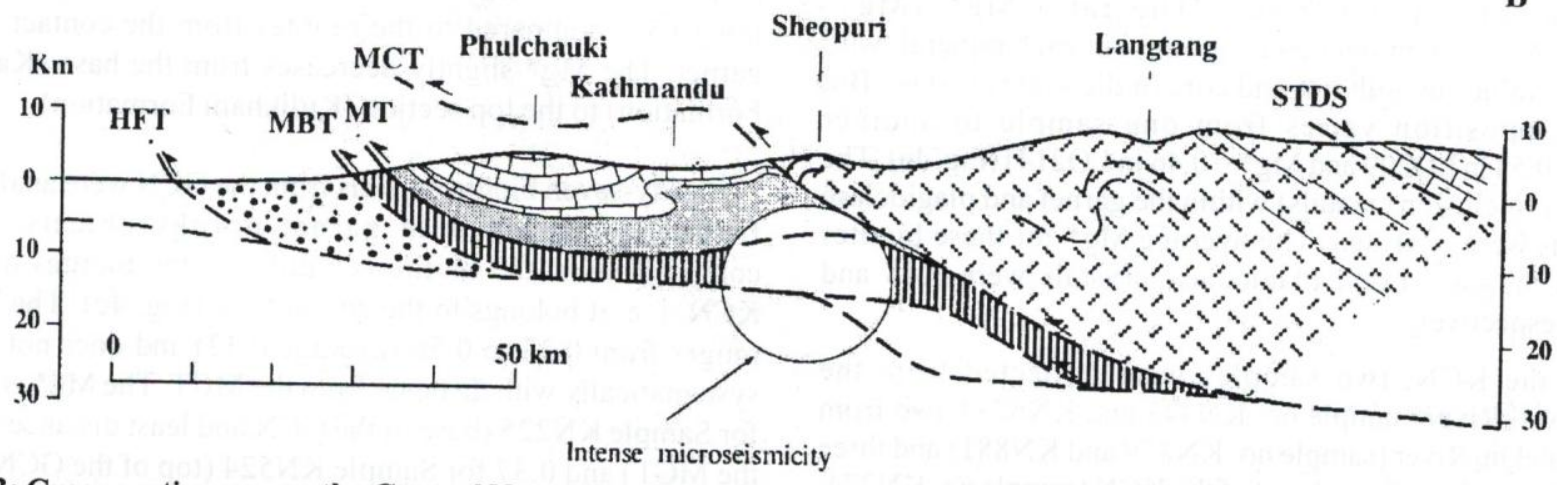

Fig. 3: Cross-section across the Central Nepal Himalaya (Upreti and Le Fort 1999) with the average P-T conditions in the different units (Rai et al. 1998) and the localisation of the intense present microseismicity (Pandey et al. 1995). GCN: Gosainkund Crystalline Nappe, KCN: Kathmandu Crystalline Nappe, LH: Lesser Himalaya, MBT: Main Boundary Thrust, MCT: Main Central Thrust, MFT: Main Frontal Thrust, MT: Mahabharat Thrust, STDS: South Tibetan Detachment System. A-B section is shown in the fig 2. 


\section{S. M. Rai et al.}

Table 1: Mineralogy of rock samples (Quartz in excess). xxx - abundant, $\mathbf{x x}$ - less abundant, $\mathbf{x}$ - rare. GCN: Gosainkund Crystalline Nappe, KCN: Kathmandu Crystalline Nappe, LH: Lesser Himalaya. For mineral name abbreviations, Bt Biotite, Chl-Chlorite, Ep-epidote, Fk-Potassium Feldspar, Gr-Garnet, Ky-Kyanite, Ms-Muscovite, Pl-Plagioclase, Ru - Rutile, Sill - Sillimanite, St - Staurolite, Tr - Tourmaline

\begin{tabular}{|c|c|c|c|c|c|c|c|c|c|c|c|c|c|c|c|}
\hline Unit & Sample & Rock type & $\mathbf{G r}$ & St & Bt & Chl & PI & Ms & Fk & $\mathbf{K y}$ & Sill & $\mathrm{Tr}$ & Ru & Fe - Ti oxides & Ep \\
\hline \multirow[t]{2}{*}{ LH } & LO209. & Schist & $x$ & & $\mathrm{xxx}$ & $x x$ & $x x x$ & & & & & & $\mathrm{x}$ & $\mathrm{x}$. & \\
\hline & $\mathrm{LO} 214$ & Schist & $\mathrm{xx}$ & $\mathrm{x}$ & $\mathrm{x}$ & $\mathrm{x}$ & & $\mathrm{xxx}$ & & & & & & $\mathrm{x}$ & \\
\hline \multirow[t]{7}{*}{$\mathrm{KCN}$} & KN274 & Schist & $\mathrm{xx}$ & & $\mathrm{xxx}$ & \multirow{7}{*}{$\mathrm{x}$} & $x x$ & $x x x$ & & & & $\mathrm{x}$ & $x$ & $\mathrm{xx}$ & $\mathrm{xx}$ \\
\hline & KN443 & Schist & $\mathrm{x}$ & & $\mathrm{xxx}$ & & $\mathrm{xxx}$ & $\mathrm{xx}$ & & & & $\mathrm{x}$ & & $\mathrm{x}$ & $\mathrm{xx}$ \\
\hline & KN623 & Schist & $x x$ & & $\mathrm{xxx}$ & & $x x x$ & $\mathrm{xx}$ & & & & $\mathrm{x}$ & $\mathrm{x}$ & $\mathrm{x}$ & \\
\hline & KN863 & Schist & $\mathrm{x}$ & & $x x$ & & $\mathrm{xx}$ & & & & & $\mathrm{x}$ & $\mathrm{x}$ & $-x x$ & $\mathrm{x}$ \\
\hline & KN876 & Schist & $\mathrm{xx}$ & & $\mathrm{xxx}$ & & $\mathrm{x}$ & $\mathrm{x}$ & & & & & $\mathrm{x}$ & $\mathrm{x}$ & \\
\hline & KN879 & Schist & $\mathrm{xxx}$ & & $\mathrm{xxx}$ & & $\mathrm{xx}$ & & & & & $\mathrm{x}$ & $\mathrm{x}$ & $\mathrm{x}$ & $\mathrm{x}$ \\
\hline & KN881 & Schist & $\mathrm{x}$ & & $\mathrm{xxx}$ & & $\mathrm{x}$ & $\mathrm{xxx}$ & & & & $\mathrm{x}$ & $\mathrm{x}$ & $\mathrm{x}$ & $\mathrm{x}$ \\
\hline \multirow[t]{9}{*}{$\mathrm{GCN}$} & KN74 & Paragneiss & $\mathrm{x}$ & & $x x$ & & $\mathrm{xx}$ & $x x x$ & $\mathrm{x}$ & & & $\mathrm{x}$ & & $\mathrm{x}$ & \\
\hline & KN87 & Paragneiss & $x x x$ & & $\mathrm{xxx}$ & & $\mathrm{x}$ & $\mathrm{x}$ & $\mathrm{xx}$ & $\mathrm{xxx}$ & $\mathrm{x}$ & & & $\mathrm{x}$ & \\
\hline & KN91 & Paragneiss & $\mathrm{xx}$ & & $\mathrm{xxx}$ & & $\mathrm{xxx}$ & $\mathrm{xx}$ & $\mathrm{x}$ & & & & $\mathrm{x}$ & $\mathrm{x}$ & \\
\hline & KN225 & Paragneiss & $\mathrm{xxx}$ & & $\mathrm{xxx}$ & & $\mathrm{xx}$ & $\mathrm{xxx}$ & & & & $\mathrm{x}$ & & $\mathrm{x}$ & \\
\hline & KN244 & Paragneiss & $\mathrm{xx}$ & & $\mathrm{xx}$ & & $x x$ & $\mathrm{xx}$ & $\mathrm{x}$ & $\mathrm{x}$ & & $\mathrm{x}$ & & & \\
\hline & KN299 & Paragneiss & $x x$ & & $\mathrm{xxx}$ & & $x x x$ & $\mathrm{xxx}$ & & & & & & $\mathrm{x}$ & \\
\hline & KN522 & Paragneiss & $\mathrm{x}$ & & $\mathrm{xxx}$ & & $\mathrm{xx}$ & $x x x$ & $\mathrm{xxx}$ & & & & & $\mathrm{x}$ & \\
\hline & KN524 & Paragneiss & $\mathrm{x}$ & & $\mathrm{xxx}$ & & $\mathrm{xxx}$ & $\mathrm{xxx}$ & & & & & & $\mathrm{x}$ & \\
\hline & KN648 & Paragneiss & $\mathrm{xxx}$ & & $\mathrm{xxx}$ & & $\mathrm{xx}$ & $\mathrm{xxx}$ & $\mathrm{x}$ & $\mathrm{xx}$ & $\mathrm{xx}$ & $\mathrm{x}$ & $\mathrm{x}$ & $\mathrm{x}$ & \\
\hline
\end{tabular}

\section{Biotite}

France-Lanord and Le Fort (1993) collected two samples from the LH (LO209 and LO214) from the mine in Lari of the Mailung Khola, Rashuwa district (Fig. 2). Nine crystals of biotite from both samples were analysed at the contact with the garnet porphyroblasts. The ratio $\mathrm{Mg}^{*}=\left(\mathrm{Mg}^{2+} /\right.$ $\left(\mathrm{Mg}^{2+}+\mathrm{Fe}^{2+}\right)$ is homogeneous throughout each mineral, with similar values in both rim and core of the same crystals. But the composition varies from one sample to another $\left(\mathrm{Mg}^{*}=0.58\right.$ in LO209 and $\mathrm{Mg}^{*}=0.46$ in LO214) (Fig. 4a). The biotites (inclusion crystals) within the garnet and plagioclase crystals were analysed. The average $\mathrm{Mg}^{*}$ for these biotites within the garnet and plagioclase crystals were 0.48 and 0.64 , respectively.

In the $\mathrm{KCN}$, two samples were collected from the Indrawati River (sample no. KN443 and KN623), two from the Malekhu River (sample no. KN879 and KN881) and three from the southern frontal part of the KCN (sample no. KN274, KN863 and KN876) (Fig. 2). Thirty-four biotite crystals from all samples were analysed from the contact within the garnet crystals. The composition of biotite in the $\mathrm{KCN}$ falls within the annite field (Fig. 4b). Like the LH biotites, the composition is homogenous; however, the value from the core biotite is limited. The $\mathrm{Mg}^{*}$ of biotites in contact with garnets of the Kalitar Formation (Stöcklin and Bhattarai 1977; Stöcklin 1980) ranges between 0.41 and 0.59 , while it varies from 0.33 to 0.49 in the Kulikhani Formation (Stöcklin and Bhattarai 1977; Stöcklin 1980). In the contact with plagioclase, it varies from 0.38 to 0.46 . The $\mathrm{Mg}^{*}$ of biotites included within garnets is low $(0.33)$ compared to the biotites from the contact with garnet. The $\mathrm{Mg}^{*}$ slightly decreases from the base (Kalitar Formation) to the top section (Kulikhani Formation).

Sixty-seven biotite crystals from the GCN were analysed from the contact with garnet porphyroblasts. The composition of the biotite is similar to the biotites of the $\mathrm{KCN}$, i. e. it belongs to the annite field (Fig. 4c). The Mg* ranges from 0.33 to 0.56 (average 0.42 ) and does not vary systematically with distance from the MCT. The $\mathrm{Mg}^{*}$ is 0.39 for Sample KN225 (base of the GCN and least distance from the MCT) and 0.37 for Sample KN524 (top of the GCN and greatest distance from the MCT). The composition of biotite in contact with garnet crystals is similar to the composition of biotites included within the garnet. The same composition can be seen for the biotite in contact with plagioclase crystals. In summary, the composition of the $\mathrm{LH}$ biotites is similar to 


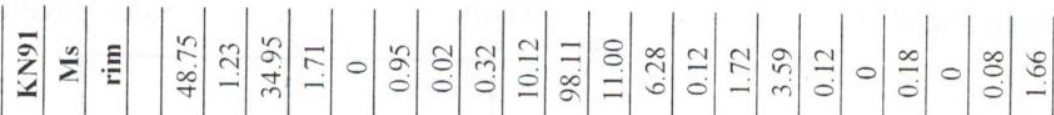

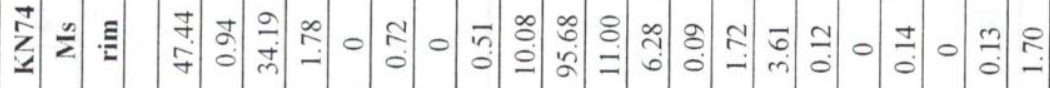

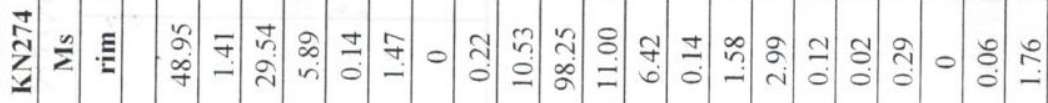

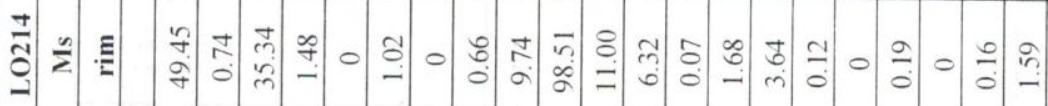

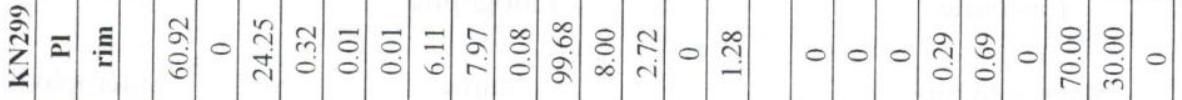

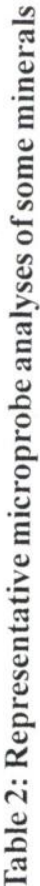

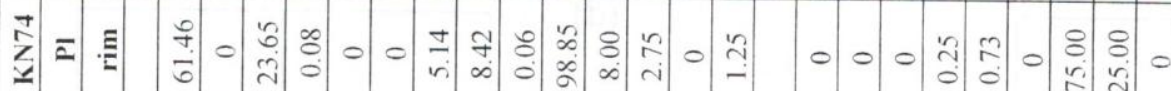

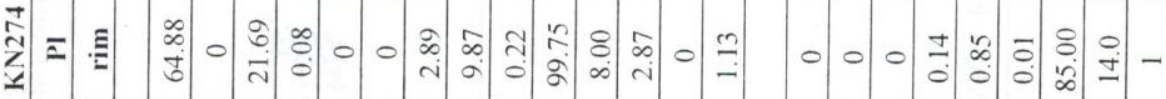

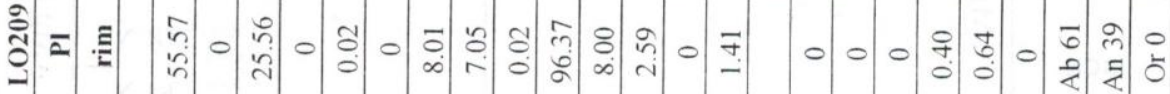

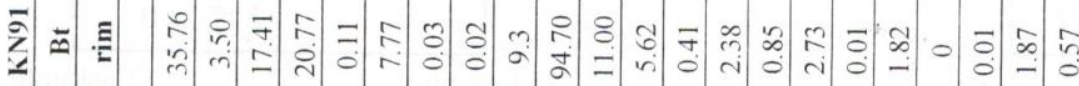

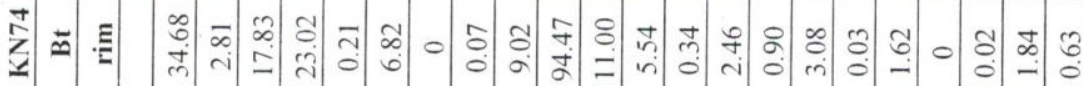

帘

至

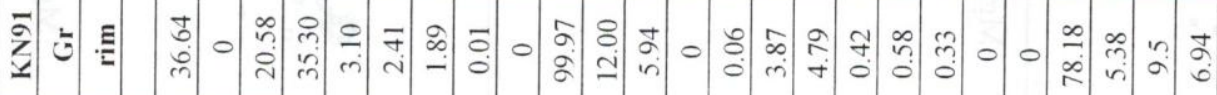

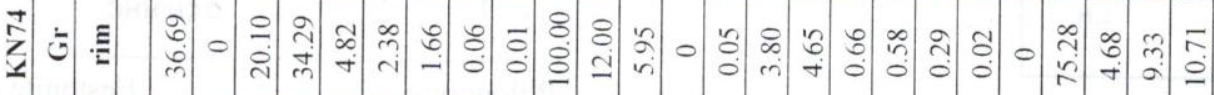

帘

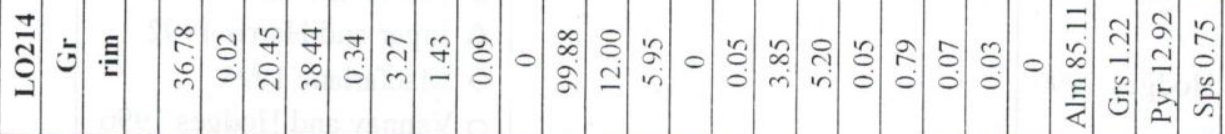

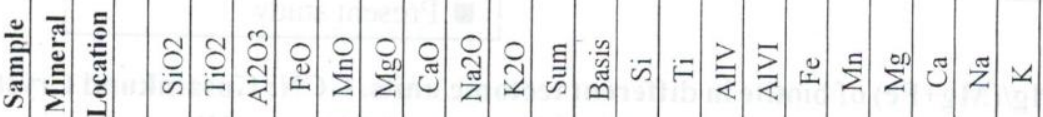


(a)

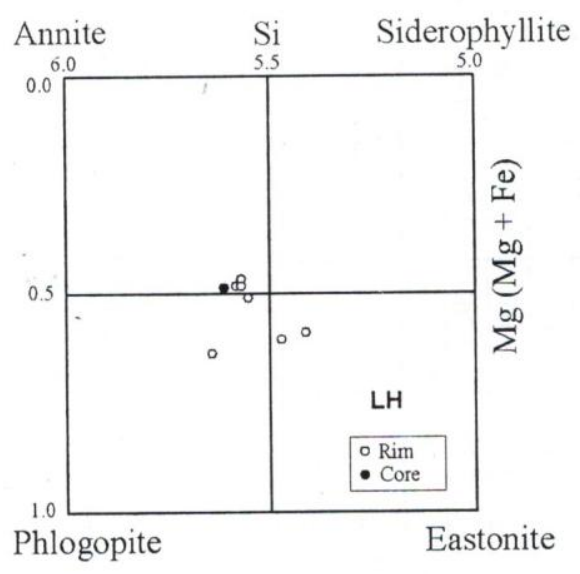

(c)

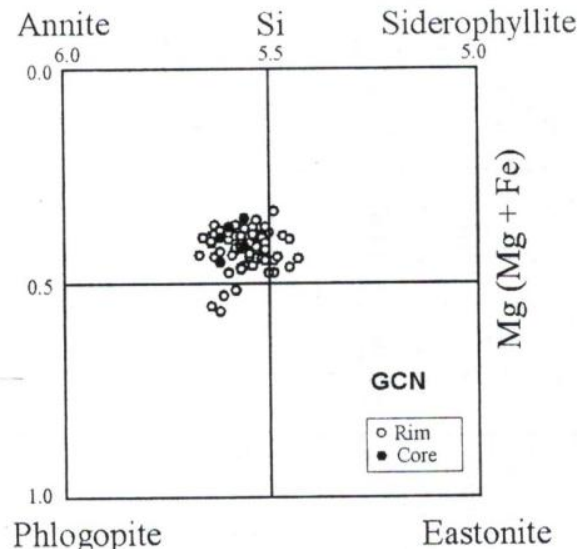

Phlogopite

Eastonite

(e)

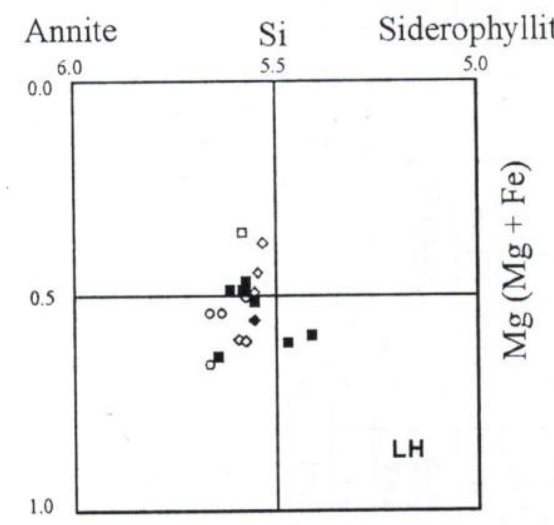

Phlogopite

Eastonite

口 Le Fort et al. 1986

$\diamond$ Macfarlane 1995

○ Vannay and Hodges 1996

Present study (b)
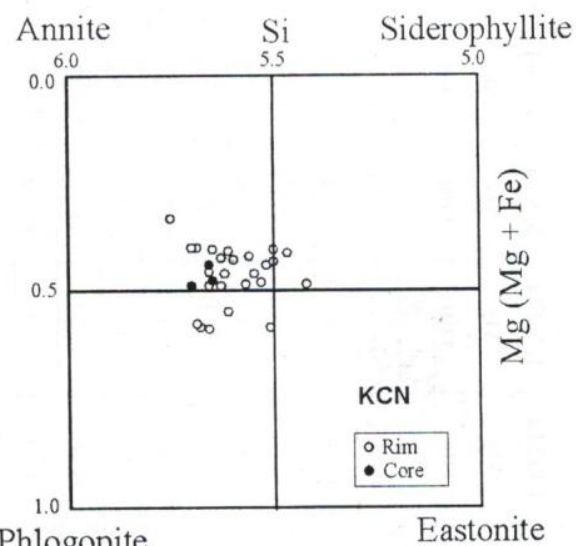

Phlogopite

(d)

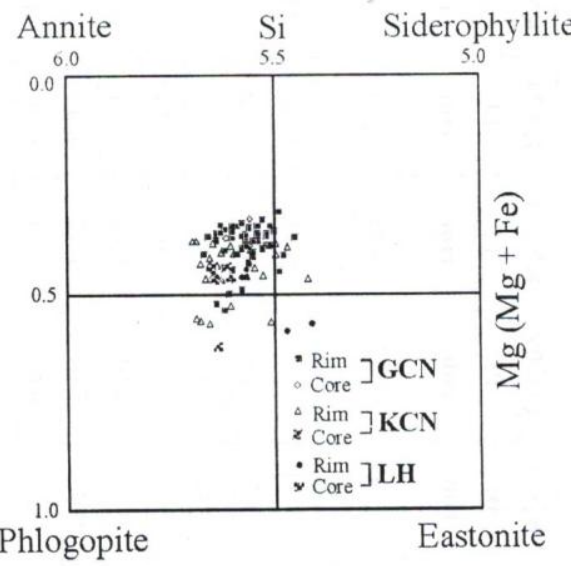

(f)

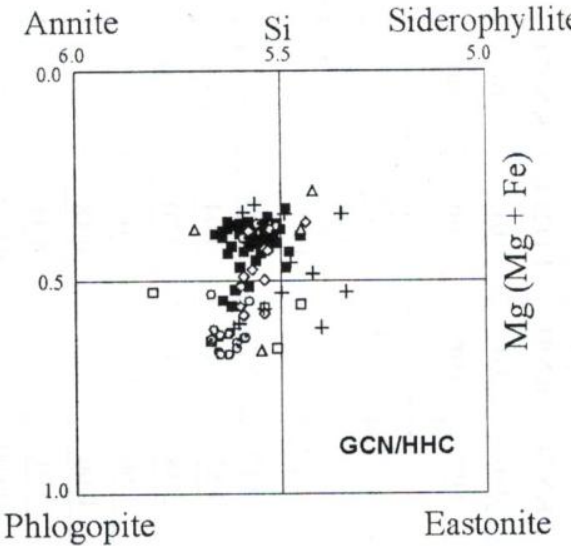

ㅁ Le Fort et al. 1986

+ France-Lanord 1987

๑ B Brouand 1989

$\Delta$ Inger and Harris 1992

$\diamond$ Macfarlane 1995

o Vannay and Hodges 1996

Present study

Fig. 4: Chemical composition ( $\mathrm{Si} / \mathrm{Mg}^{*}=\mathrm{Mg} /(\mathrm{Mg}+\mathrm{Fe})$ of biotite in different tectonic units. GCN: Gosainkund Crystalline Nappe, HHC: Higher Himalayan Crystalline, KCN: Kathmandu Crystalline Nappe, and LH: Lesser Himalaya 
the composition of the biotites from the $\mathrm{KCN}$ and the GCN. In general, the biotites of these three units are annites in composition (Fig. 4d).

Many authors have studied the chemistry of biotites especially in the Annapurna-Manaslu-Ganesh Himal area (Arita 1983; Le Fort et al. 1986; Pêcher and Le Fort 1986; France-Lanord 1987; Brouand 1989; Guillot 1993; Kaneko 1997; Vannay and Hodges 1996, Poudel and Arita 2002), Langtang area (Macfarlane 1995; Inger and Harris 1992), and in the east of Kathmandu (Maruo and Kizaki 1983). Kaneko(1997) noted that the composition of most of the biotites from the MCT zone or upper section of the LH in the Annapurna region falls in the field of phlogopite. Le Fort et al. (1986), Vannay and Hodges (1996) noted the same composition of biotites of the $\mathrm{LH}$ in this region (Fig. 4e). The composition studied by Macfarlane (1995) falls in the field of phlogopiteannite (Fig. 4e), as well as Vannay and Hodges (1996) and Kaneko (1997) noted the phlogopitic composition from the HHC (Fig. 4f). Le Fort et al. (1986), found the phlogopitic biotites in calcic gneiss of the Tibetan Slab along the Kali Gandaki section. The compositions from the present study (Fig. 4f) are similar to the compositions found in the Langtang section (Macfarlane 1995). The compositions from the gneiss of the Formation I (Tibetan Slab) are dispersed (France-Lanord 1987; Inger and Harris 1992). Indeed, Brouand (1989) found that the biotite compositions from the migmatites of the Formation I include both the annite and phlogopite fields with an evolution toward the high-magnesium (phlogopite) pole. The $\mathrm{Mg}^{*}$ for biotites from the $\mathrm{HHC}$ is higher than the $\mathrm{Mg}^{*}$ for biotites from the MCT zone and the LH (Arita 1983; Le Fort et al. 1986).

The Ti content in biotite ranges from 0.04 to 0.19 in the $\mathrm{LH}$, from 0.12 to 0.45 in the $\mathrm{KCN}$, and from 0.20 to 0.50 in the GCN. The lower content of Ti from the LH biotites clearly distinguishes from the other two units (Figs. 5a and 5b), suggesting lower metamorphic conditions. The relation $\mathrm{Ti} /$ $\mathrm{Mg}^{*}$ for the other two nappes is very much similar (Fig. 5a). The $\mathrm{Ti} / \mathrm{Mg}^{*}$ does not show any relation with the grade of metamorphism above the MCT (Fig. 5c). This suggests that the composition of high- grade biotite is mainly controlled by the initial composition of the rocks.

\section{Muscovite}

The muscovites from the $\mathrm{LH}$ show an average $\mathrm{Al}_{2} \mathrm{O}_{3}$ content of $35 \%$ and average $\mathrm{FeO}$ content of $1.5 \%$ (Fig. $6 \mathrm{a}$ ). The average contents of $\mathrm{Al}_{2} \mathrm{O}_{3}$ and $\mathrm{FeO}$ in the $\mathrm{KCN}$ are $31 \%$ and $4.8 \%$, respectively (Fig. $6 \mathrm{a}$ ). The average contents of $\mathrm{Al}_{2} \mathrm{O}_{3}$ and $\mathrm{FeO}$ in the $\mathrm{GCN}$ are $33 \%$ and $1.7 \%$, respectively (Fig. 6a). The muscovites from the $\mathrm{KCN}$ are generally rich in $\mathrm{Fe}$ while the muscovites of other units are more aluminous (Fig. 6a).

In the $\mathrm{LH}$ (Fig. 6b), only one sample is very rich in $\mathrm{FeO}$ (Le Fort et al. 1986). The muscovites from the LH are slightly rich in FeO (Macfarlane 1995, Vannay and Hodges 1996). The muscovites from the study area are very poor in $\mathrm{FeO}$ and rich in $\mathrm{Al}_{2} \mathrm{O}_{3}$ with respect to the compositions observed by other authors. In the HHC (Fig 6c), the composition of muscovites is variable, particularly the proportion of $\mathrm{FeO}$ (1-3.5\%) (Le Fort et al. 1986; Brouand 1989; Inger and Harris 1992; Macfarlane 1995; Vannay and Hodges 1996). The composition of muscovites from the study area is very similar to the composition found by Macfarlane (1995) and Vannay and Hodges (1996). The composition of muscovites depends on both the composition of the protolith and the grade of metamorphism (Le Fort et al. 1986).

For all units, the average Ti contents for both biotite and muscovite are directly related to each other (Fig. 6d). By contrast, the XFe ratio $\left(\mathrm{Fe}^{2+} / \mathrm{Fe}^{2+}+\mathrm{Mg}^{2+}\right)$ for biotite and muscovite is not clearly related to each other (Fig. 6e).

\section{Garnet}

In the LH two samples for the study of garnet chemistry (LO209 and LO214) were collected close to the MCT. The garnet composition of sample LO209 was almandine 63-66\%, grossular $16-21 \%$, pyrope $15-18 \%$, and spessartine $1-3 \%$, while the garnet composition of sample LO214 is almandine $84-88 \%$, grossular $1-6 \%$, pyrope $6-13 \%$, and spessartine $1-3 \%$. They are, in average, rich in almandine $(63-88 \%)$, poor in spessartine $(1-3 \%)$, with variable contents of grossular and pyrope. The profile of garnet (LO214) showed a homogenous composition, except at the rim, where grossular and pyrope slightly decreased (Fig. 7a; Rai et al. 1998). In the LH, Arita (1983), Le Fort et al. (1986), and Kaneko (1997) made the same observation on the chemistry of garnets that is found in the present study. Arita (1983), Le Fort et al. (1986), Macfarlane (1995), Kaneko (1997) pointed out the normal zonation of rich spessartine content in the core and rich almandine content in the rim. However, the garnets from the study area did not show such a relationship.

The garnets from the Kalitar Formation of the $\mathrm{KCN}$ are richer in almandine and pyrope than the garnets of the Kulikhani Formation (KCN). By contrast, the garnets of the Kulikhani Formation are richer in grossular and spessartine. The average composition of the garnets is almandine $43 \%$, grossular 20\%, pyrope $4 \%$, and spessartine $33 \%$ (Kulikhani Formation) and almandine $62 \%$, grossular $15 \%$, pyrope $11 \%$, and spessartine 12\% (Kalitar Formation). Sample KN274 (Kalitar Formation) showed the normal zoning pattern of decrease in almandine content toward the rim (Fig. 7b; Rai et al. 1998). The average composition in this crystal, from the core to rim, varies from almandine $29 \%$, grossular $19 \%$, pyrope $1 \%$, and spessartine $51 \%$ to almandine $42 \%$, grossular $20 \%$, pyrope $3 \%$, and spessartine $35 \%$. Maruo and Kizaki (1983) observed such a zonation in garnets from east of the Kathmandu Valley. The enrichment of $\mathrm{Fe}$ and $\mathrm{Mg}$ and depletion in $\mathrm{Mn}$ and $\mathrm{Ca}$ from the core to the rim of the garnet is characteristics of prograde metamorphism.

The garnets from the GCN were systematically analysed from the base (sample KN225) to the top section (sample KN524). The garnets were rich in almandine (60-85\%), but the spessartine content varied (3-16\%). The grossular and 
(a)

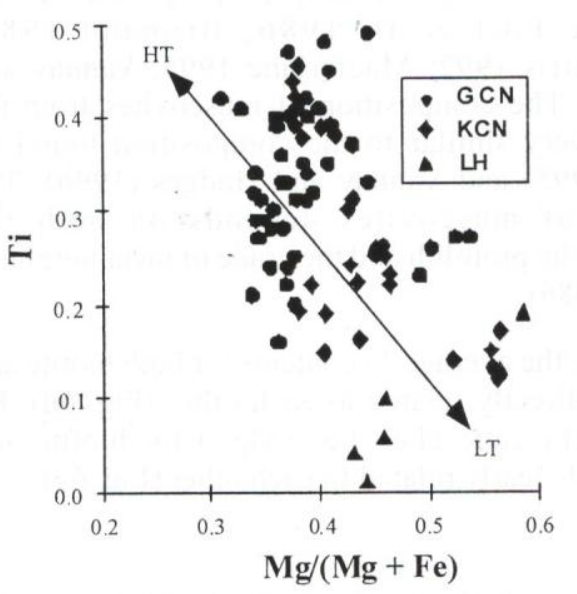

(b)

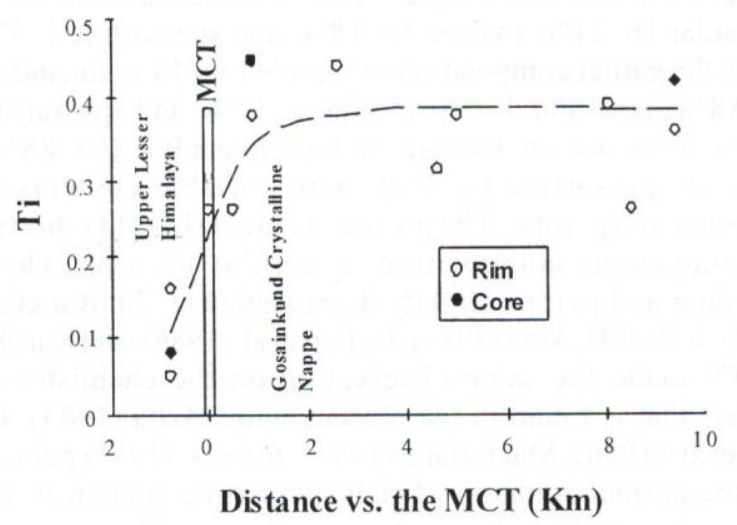

(c)

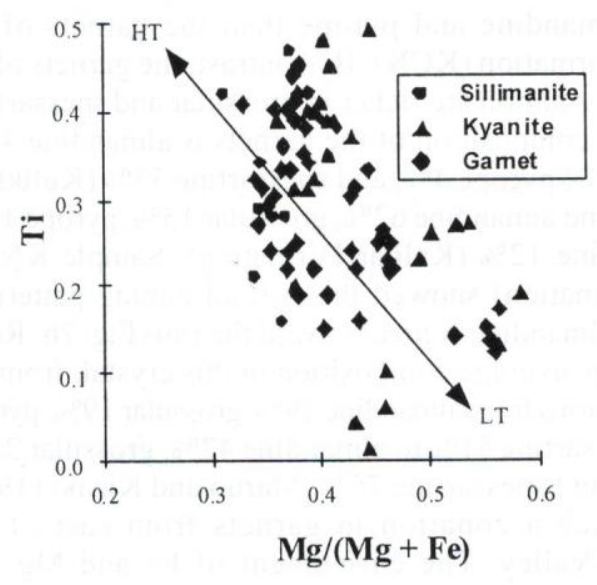

Fig. 5: Chemical composition $\left(\mathrm{Ti} / \mathrm{Mg}^{*}=\mathrm{Mg} /(\mathrm{Mg}+\mathrm{Fe})\right.$ of biotite in different tectonic units. GCN: Gosainkund Crystalline Nappe, KCN: Kathmandu Crystalline Nappe, LH: Lesser Himalaya, MCT: Main Central Thrust, LT: Low Temperature, HT: High Temperature pyrope contents varied from 3 to $21 \%$, and from 6 to $15 \%$, respectively. Garnets (sample KN87) showed nearly homogeneous composition with a very slight increase in almandine and spessartine contents with corresponding depletion in grossular content near the rim (Fig. 7c) (Rai et al. 1998). These garnets had a reverse pattern at their outermost margins. $\mathrm{FeO}$ increased and $\mathrm{MgO}$ decreased toward the rim. Such a trend can be interpreted as growth during retrogression, but the restriction of this trend to the outer rim suggests retrogressive re-equilibrium by internal diffusion (Loomis 1986; Spear 1988). The composition of garnet from the base to the top section does not show any systematic variation, but in the upper section, where the sillimanite appears, the almandine content decreases and spessartine content slightly increases (Fig. 7d).

In the HHC, equivalent to the GCN, Arita (1983), Le Fort et al. (1986), Pêcher and Le Fort (1986), Macfarlane (1995), and Kaneko (1997) described pyrope-rich garnets and inverse zonation. In this study area, the slight increase in almandine and spessartine contents and the decrease in grossular content towards the rim could correspond to the final stage in retrogression where re-equilibrium occurred due to internal diffusion (Loomis 1986, and Spear 1988).

\section{Plagioclase}

The plagioclase crystals from the $\mathrm{LH}$ were analysed from only one sample (LO209). The composition was anorthite $52-64 \%$, albite $39-56 \%$. The plagioclase crystals from the $\mathrm{KCN}$ is not zoned. The average composition of plagioclase from the Kalitar Formation and the Kulikhani Formation is albite $84 \%$ and albite $69 \%$, respectively. The albite content decreases from the lower to upper section in the nappe. The average composition changes from oligoclase to labradorite (albite 56-89\% and albite 58-88\%). The plagioclase from the GCN was analysed from both the matrix and inclusion in garnets. The chemical compositions are homogenous between the matrix and the inclusions (albite 78\%, anorthite $21 \%$ versus albite $79 \%$, anorthite $21 \%$ ). Profiles across a few crystals showed homogeneity from the core to rim \{Fig. 8 (a) KN299 and Fig. 8 (b) KN 522$\}$. There is no systematic chemical variation from the bottom to the top section in the GCN.

\section{P-T ESTIMATES}

The LH comprises metamorphic rocks of greenschist facies in the proximity of the MT and amphibolite facies in the proximity of the MCT, respectively. The Bhimphedi Group of the KCN consists of amphibolite facies crystalline rocks and the bottom section of the Phulchauki Group consists of the greenschist facies metasediments and gradually changes to sedimentary rocks towards the top. The GCN is composed of very high-grade metamorphic crystalline rocks (from amphibolite to granulite facies).

Rai et al. (1998) described the P-T conditions of the study area. The LH samples recorded syn-MCT metamorphic conditions of $750 \pm 150 \mathrm{MPa}$ and $566 \pm 136{ }^{\circ} \mathrm{C}$. The P-T 
(a)

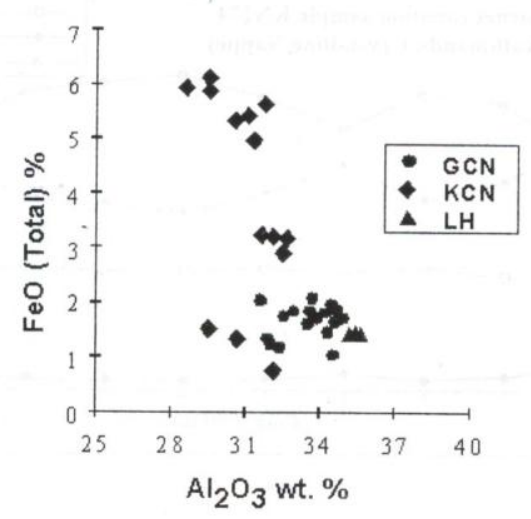

(b)

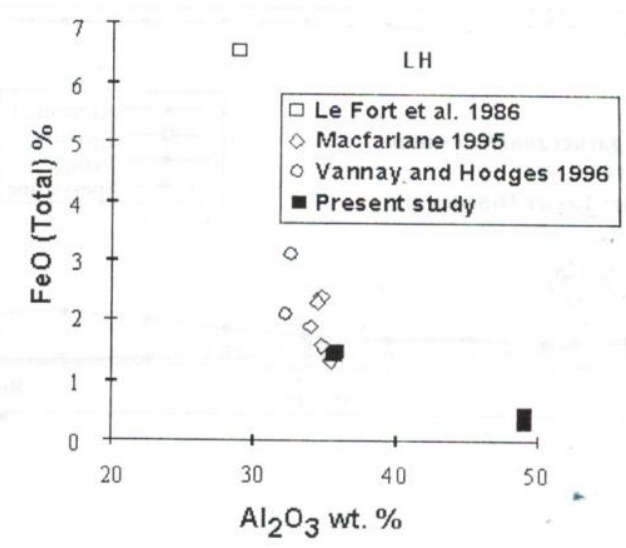

(c)

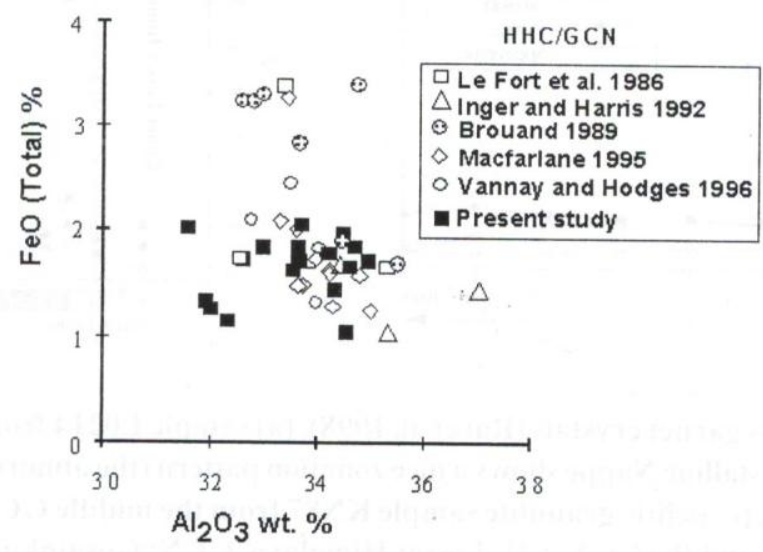

(d)

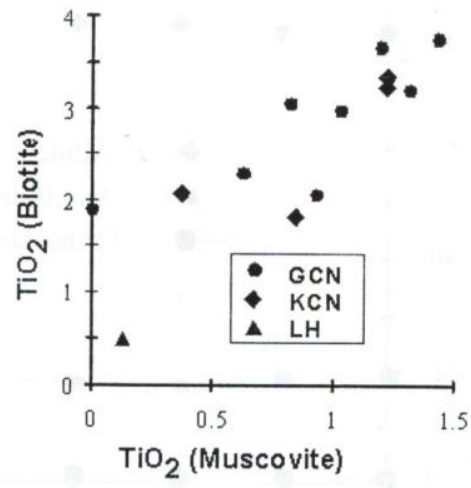

(e)

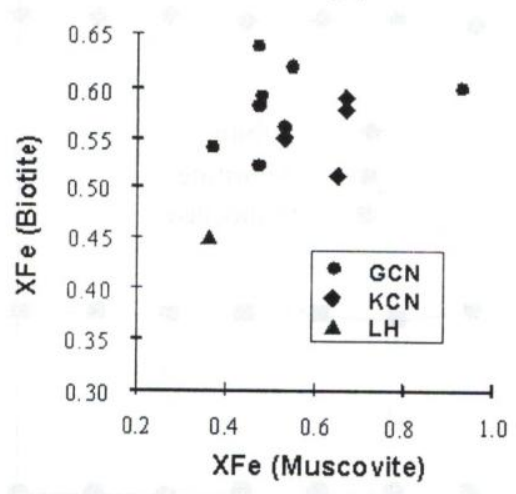

Fig. 6: Chemical composition $\left(\mathrm{FeO} / \mathrm{Al}_{2} \mathrm{O}_{3}\right.$ ) of muscovite and $\mathrm{TiO}_{2}$ composition between biotite and muscovite in different tectonic units. GCN: Gosainkund Crystalline Nappe, HHC: Higher Himalayan Crystalline, KCN: Kathmandu Crystalline Nappe, and LH: Lesser Himalaya 


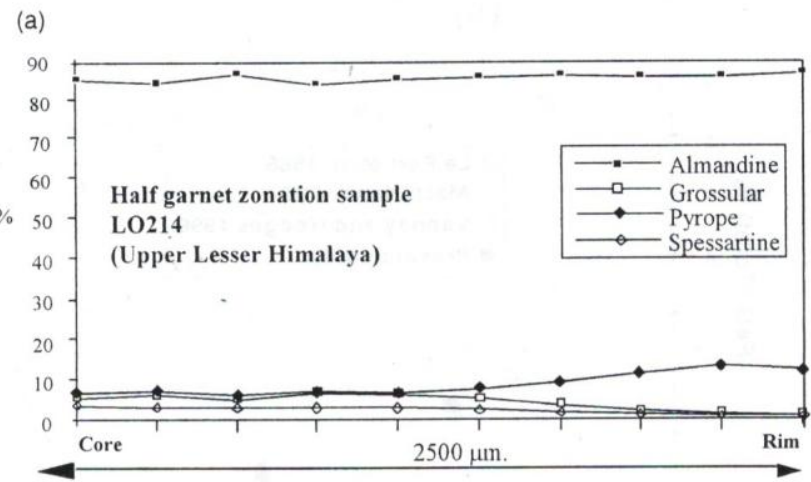

(c)

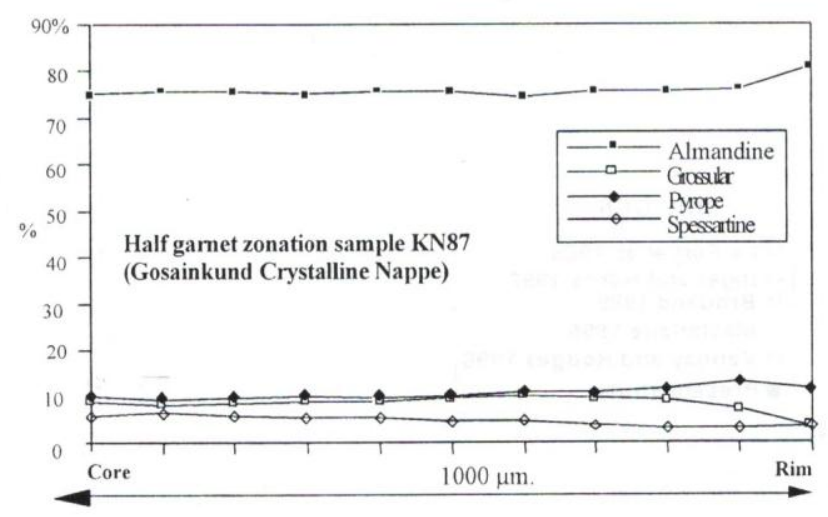

(b)

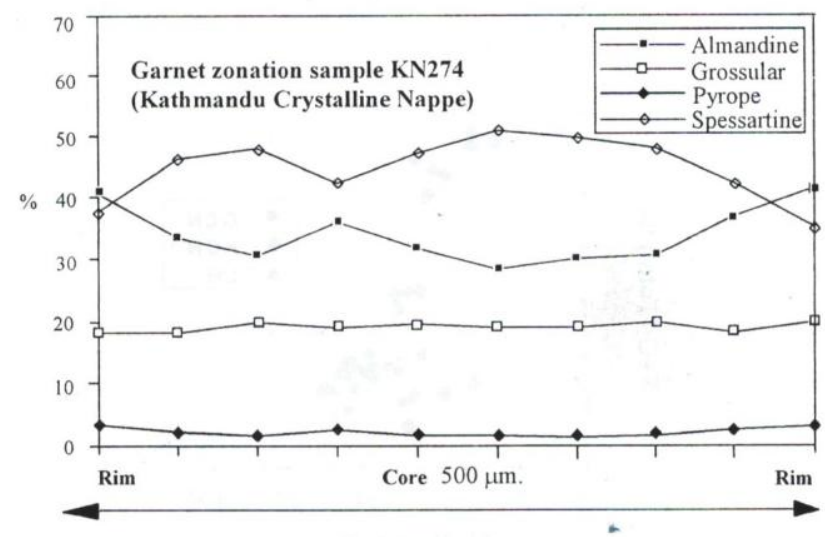

(d)

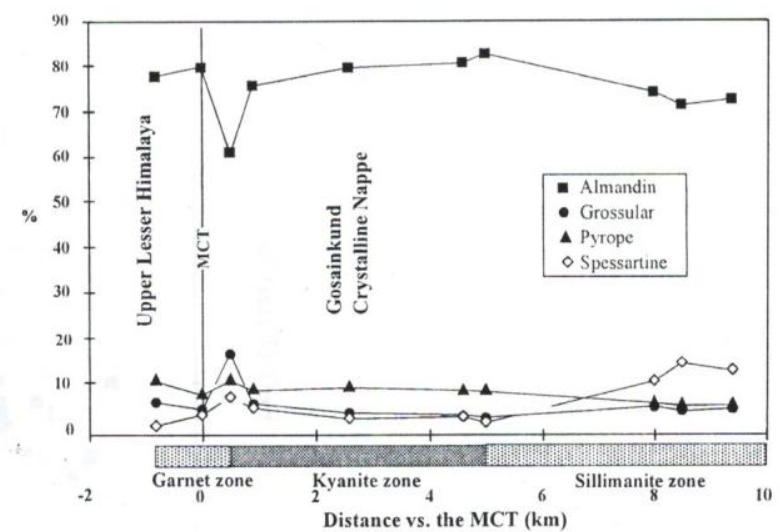

Fig. 7: Microprobe profiles across garnet crystals (Rai et al. 1998). (a) sample L0214 from the Lesser Himalaya, (b) sample KN274 from the Kathmandu Crystalline Nappe shows a nice zonation pattern (the abnormal intermediate point corresponds to a small fracture in the crystal), (c) pelitic granulite sample KN87 from the middle GCN, and (d) compositional variation of the different garnets in the LH and the GCN, LH: Lesser Himalaya, GCN: Gosainkund Crystalline Nappe, MCT: Main Central Thrust

(a)

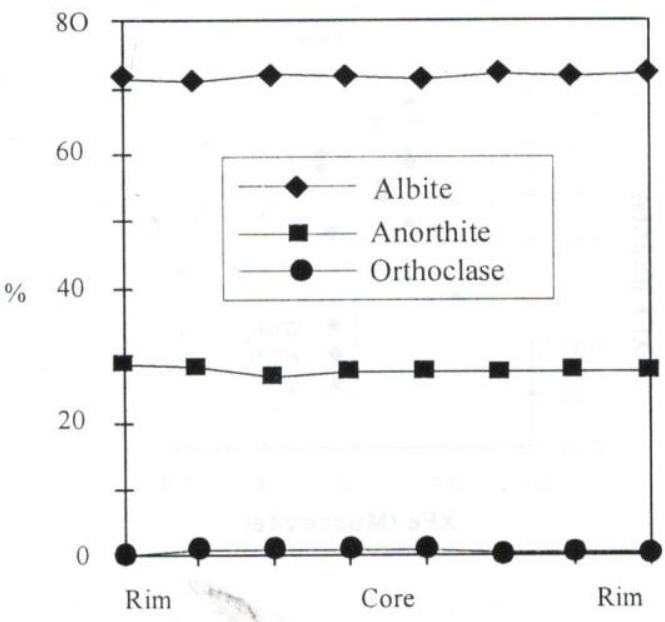

(b)

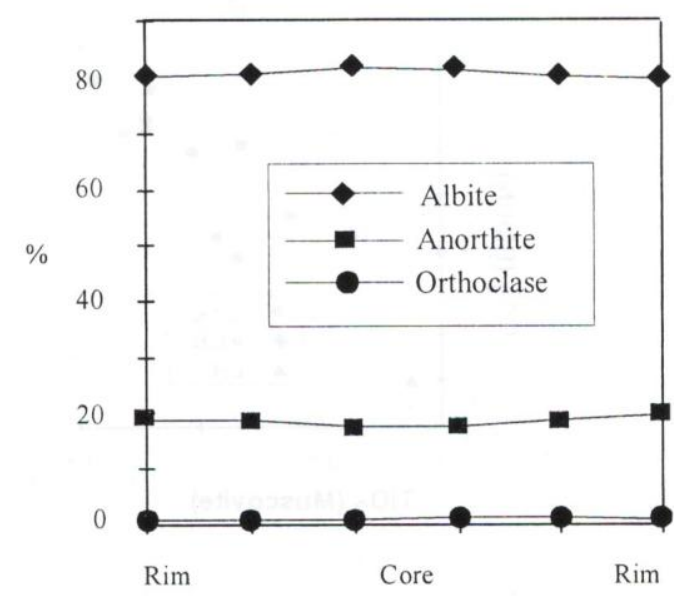

Fig. 8: Microprobe profile across plagioclase crystal. (a) Sample KN299 from the base of the Gosainkund Crystalline Nappe, (b) ) sample KN522 from the upper section of the Gosainkund Crystalline Nappe 
(a)

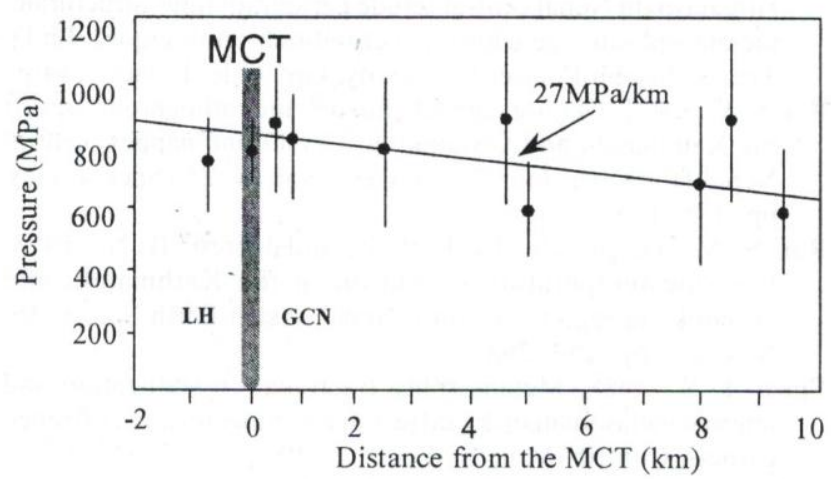

(b)

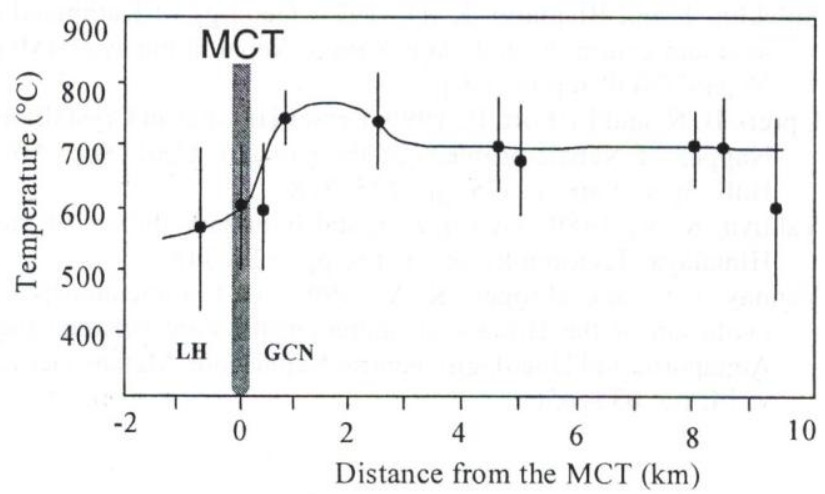

Fig. 9: P-T evolution versus MCT distance (Rai et al. 1998), GCN: Gosainkund Crystalline Nappe, LH: Lesser Himalaya

conditions recorded in the $\mathrm{KCN}$ range from $900 \mathrm{MPa}$ to 720 $\mathrm{MPa}$ and $700{ }^{\circ} \mathrm{C}$ to $485^{\circ} \mathrm{C}$, while the GCN recorded the P-T conditions ranging from $890 \mathrm{MPa}$ to $580 \mathrm{MPa}$ and $750{ }^{\circ} \mathrm{C}$ to $590{ }^{\circ} \mathrm{C}$ (Fig. 9). These P-T conditions show the preservation of inverse metamorphism in the $\mathrm{LH}$ below the MCT. In case of the $\mathrm{KCN}$, the average $\mathrm{P}-\mathrm{T}$ increased from the frontal part $\left(755 \pm 50 \mathrm{MPa}, 512 \pm 22{ }^{\circ} \mathrm{C}\right)$ to the interior part $(879 \pm 29$ $\mathrm{MPa}, 686 \pm 20{ }^{\circ} \mathrm{C}$ close to the MCT). The temperatures recorded in the $\mathrm{KCN}$ are about $100{ }^{\circ} \mathrm{C}$ lower than those recorded in the GCN. These data are consistent with the lower temperature recorded in the $\mathrm{KCN}$, suggesting that this unit rested at the same depth for a shorter duration than the GCN (Guillot and Allemand 2002). The difference in temperature clearly shows that the GCN and the $\mathrm{KCN}$ are two distinct units as also supported by evidence from their lithology, stratigraphy, and metamorphism (Upreti and Le Fort 1999). The consistency of P-T estimates in the MCT and the MT zones suggests that the main deformation was synmetamorphic and probably records the underthrusting of the $\mathrm{LH}$ below the $\mathrm{HHC}$ along the MCT or below the $\mathrm{KCN}$ along the MT.

\section{CONCLUSIONS}

The variation in chemistry of four minerals (biotite, muscovite, garnet, and plagioclase) from one unit to another suggests that they are separate tectonic units. In the $\mathrm{KCN}$, the almandine and pyrope contents in garnet decreased from the bottom to top section, while the grossular and spessartine contents increased, which was consistent with the progressive metamorphism observed in the field. The composition of garnets from the bottom to top section of the GCN did not show any systematic variation, but in the upper section, where the sillimanite appeared, the almandine content decreased, and the spessartine content slightly increased. This variation in composition is consistent with polyphase metamorphism. The P-T conditions record the preservation of inverse metamorphism in the $\mathrm{LH}$ and below the MCT. A comparison of P-T results of the GCN with those of the $\mathrm{KCN}$ suggests that the exhumation of the $\mathrm{KCN}$ was followed by the exhumation of the GCN.

\section{ACKNOWLEDGMENTS}

The authors wish to express their sincere thanks to Dr $\mathrm{S}$. Emerman for his critical reading and improvement of the manuscript. The fieldwork was supported by CNRS, France, and Main Himalayan Thrust project organised by Professor Dr Harutaka Sakai, Kyushu University, Japan for which the authors are very much thankful. The first author is grateful to the Foreign Ministry of France for providing the $\mathrm{Ph}$. D. scholarship in Grenoble, France.

\section{REFERENCES}

Arita, K., 1983, Origin of the inverse metamorphism of the Lower Himalayas, central Nepal. Tectonophysics, v. 95, pp. 43-60. Brouand, M., 1989, Pétrogenèse des migmatites de la Dalle du Tibet (Himalaya du Népal). Ph. D. Thesis, Ins. Natl. Polytech. Lorraine, Nancy, 224 p.

France-Lanord, C., 1987, Chevauchement, métamorphisme et magmatisme en Himalaya du Népal. Etude isotopique H, C, O. Ph. D. Thesis, Nancy, 202 p.

Fuchs, G. R., 1981, Geological-Tectonical map of the Himalaya. Geol. Surv. Austria, Scale 1:2,000,000

Gansser, A., 1964, Geology of the Himalaya: Interscience Publisher, London, 289 p.

Guillot, S., 1993, Le granite du Manaslu (Nepal central) : Marquer de la subduction et de l'extension intracontinentales himalayennes. Etude structurale, metamorphique et géochimique. Ph. D. Thesis, Univ. Joseph Fourier, Mém. Géologie Alpine, v. 19, 95 p.

Guillot, S. and Allemand, P., 2002, Two-Dimensional Thermal Modelling of the early tectonometamorphic evolution in Central Himalaya. Jour. Geodynamics. v. 34, pp. 77-98.

Hashimoto, S., Ohta, Y., and Akiba, C., 1973, Geology of the Nepal Himalaya. Saikon Publ. Co. Sapporo, Japan, 486 p.

Inger, S., and Harris, N. B. W., 1992, Tectonothermal evolution of the High Himalayan Crystalline Sequence, Langtang valley, northern Nepal. Jour. Metam. Geol., v. 10, pp. 439-452.

Kaneko, Y., 1997, Two-step exhumation model of the Himalayan Metamorphic Belt, central Nepal. Jour. Geol. Soc. Japan, v. 103, pp. 203-226.

Le Fort, P., 1975, Himalaya: the collided range. Present knowledge of the continental arc. Am. Jour. Sci., v. 275A, pp. 1-44.

Le Fort, P., Pêcher, A., and Upreti, B. N., 1986, A section through the Tibetan Slab in central Nepal (Kali Gandaki valley): mineral 
chemistry and thermobarometry. In : Evolution des domaines orogéniques d'Asie méridionale (de la Turquie à l'Indonésie), P. Le Fort, M. Colchen and C. Montenat (eds.), Mém. Sci. de la Terre, Nancy, v. 47, pp. 211-228.

Loomis, T. P., 1986, Metamorphism of metapelites: calculations of equlibrium assemblages and numerical simulations of the crystallization of garnet. Jour. Metam. Geol., v. 4, pp. 209-229.

Macfarlane, A. M., 1995, An evaluation of the inverted metamorphic gradient at Langtang National Park, central Nepal Himalaya. Jour. Metam. Geol., v. 13, pp. 595-612.

Maruo, Y. and Kizaki, K., 1983, Thermal structure in the nappe of eastern Nepal Himalayas. In, Granites of Himalaya, Karakorum and Hindukush, F. A. Shams (ed.), Institute of Geology, Punjab Univ. Lahore, Pakistan, pp. 271-286.

Pandey, M. R., Tandukar, R. P., Avouac, J. P., Lavé, J. and Massot, J. P., 1995, Interseismic strain accumulation on the Himalayan crustal ramp (Nepal). Geophys. Res. Lett, v. 22, pp. 751-754.

Poudel, L. P., and Arita, K., 2002, Locating the Main Central Thrust in central Nepal using lithologic, microstructural and metamorphic criteria. Jour. Nepal Geol. Soc., v. 26, pp. $29-42$.

Pêcher, A., 1989, The metamorphism in Central Himalaya. Jour. Metam. Geol., v. 7, pp. 31-41.

Pêcher, A. and Le Fort, P., 1986, The metamorphism in central Himalaya : its relations with the thrust tectonics. In : Evolution des domaines orogéniques d'Asie méridionale (de la Turquie à l'Indonésie), P. Le Fort, M. Colchen and C. Montenat (eds.), Sci. de la Terre, Nancy, France, v. 47, pp. 285-309.
Rai, S. M., 1998, Les nappes de Katmandou et du Gosainkund, Himalaya du Népal central (étude cartographique, structurale, métamorphique, géochimique et radiochronologique). Ph.D. Thesis, Joseph Fourier University, Grenoble, France, 244 p.

Rai, S. M., 2001, Geology, geochemistry, and radiochronology of the Kathmandu and Gosainkund Crystalline nappes, central Nepal Himalaya. Jour. Nepal Geol. Soc., v. 25 (Spec. Issue), pp. 135-155.

Rai, S. M., Guillot, S., Le Fort, P., and Upreti, B. N., 1998, Pressure-temperature evolution in the Kathmandu and Gosainkund regions, Central Nepal. Asian Earth Sci., v. 16, Nos. 2-3, pp. 283-298.

Spear, F. S., 1988, Metamorphic fractional crystallization and internal metasomatism by diffusional homogenization of zoned garnets. Contrib. Mineral. Petrol., v. 98, pp. 507-517.

Stöcklin, J., 1980, Geology of the Nepal and its regional frame Jour. Geol. Soc., London, v. 137, pp. 1-34.

Stöcklin, J. and Bhattarai, K. D., 1977, Geology of Kathmandu area and central Mahabharat Range, Nepal Himalaya. HMG Nepal/UNDP report, $64 \mathrm{p}$.

Upreti, B. N. and Le Fort, P., 1999, Lesser Himalayan Crystalline Nappes of Nepal, problem of their origin. Geol. Soc. Am. Bull. Spec. Pap., v. 328, pp. 225-238.

Valdiya, K. S., 1980, Two intracrustal boundary thrusts of the Himalaya. Tectonophysics, v. 66, pp. 323-348.

Vannay, J. C. and Hodges, K. V., 1996, Tectonometamorphic evolution of the Himalayan metamorphic core between the Annapurna and Dhaulagiri, central Nepal. Jour. Metam. Geol., v. 14 , pp. $635-656$. 